\title{
PENGENALAN TEMPRAMEN DASAR ABRAHAM, MUSA, PETRUS DAN PAULUS DALAM PENDIDIKAN AGAMA KRISTEN
}

\author{
Wahju A. Rini \\ Universitas Kristen Indonesia \\ Wahyuarini10862@gmail.com
}

\begin{abstract}
Abstrak
Temperamen merupakan kombinasi dari sifat-sifat bawaan sejak lahir, terdapat empat macam yaitu Sanguin, Kolerik, Melankolis dan Plegmatis, masing masing memiliki kelemahan dan kelebihan. Temperamen merupakan bahan dasar yang membentuk watak dan kepribadian manusia, masingmasing memiliki keunikan, satu dengan yang lain berbeda secara mendasar, baik dalam pikiran, perasaan maupun keinginan (Stanley Heath, 1999). Penelitian ini bertujuan untuk mengenal temperamen dasar dari Abraham, Petrus dan Paulus sebagai salah satu cara untuk mempersiapkan generasi yang berkarakter dan menjadi salah satu tugas dalam pembelajaran Pendidikan Agama Kristen (PAK).

Untuk itu pendekatan yang digunakan dalam penelitian ini adalah kualitatif. Berdasarkan hasil studi pustaka dari berbagai sumber, yaitu sejumlah literatur berbahasa Indonesia dan Inggris untuk mengenal temperamen dasar Abraham, Musa, Petrus dan Paulus dalam pembelajaran Pendidikan Agama Kristen (PAK).

Penelitian ini memberikan gambaran bahwa temperamen merupakan bahan dasar yang mewarnai hidup seseorang. Abraham yang memiliki temperamen dasar Flegmatik, memperlengkapi Abraham dengan kekuatannya yang menonjol yaitu taat, iman, pendoa, diplomasi, pengasih dan pendamai, sehingga sanggup melaksanakan perintah Allah untuk keluar dari tempat asalnya ke negeri yang dijanikan Allah dan menjadi saksi Allah di tengah-tengah bangsa yang belum mengenal-Nya. Musa yang memiliki temperamen dasar Melankolis, kekuatannya terletak pada kesetiaannya akan visi untuk membawa bangsa Israel keluar dari Mesir menuju tanah perjanjian. Petrus yang memiliki temperamen dasar Sanguin, kekuatannya, yaitu ramah da pandai berbicara. Tuhan memperlengkapi Petrus sehingga memiliki kepandaian untuk berkhotbah, untuk mengukir sejarah berdirinya gereja mula-mula. Paulus yang Kolerik, Tuhan memperlengkapi Paulus yang memiliki ketajaman intuisi untuk melakukan pekerjaan Allah yang dahsyat. Paulus seorang Kolerik yang berani untuk keluar, memberitakan injil kepada bangsa-bangsa yang belum mengenal Allah. Hasilnya telah terjadi penginjilan secara lintas budaya, keberaniannya menembus batas tembok penyekat antar budaya dan bangsa, membuat Gereja dapat berdiri di seluruh bumi.

Manfaat yang didapat melalui pengenalan temperamen dalam PAK adalah, dimana Tuhan memanggil Abraham, Musa, Petrus dan Paulus sesuai dengan kekuatan dan kelemahan temperamen dasar masing-masing, dapat memberi inspirasi bagi peserta didik untuk menjalani panggilan dan tujuan hidupnya sesuai dengan kehendak Allah.
\end{abstract}

Kata kunci: Temperamen, Flegmatik, Melankolik, Sanguin, Kolerik, Pendidikan Agama Kristen 


\section{Pendahuluan}

Pendidikan Agama Kristen (PAK) menjadi tulang punggung dalam membangun generasi yang berkarakter, seperti Firman Tuhan yang tertulis dalam 2 Korintus 5:17: "Jadi siapa yang ada di dalam Kristus, ia adalah ciptaan baru: yang lama sudah berlalu, sesungguhnya yang baru sudah datang." Implikasinya yaitu manusia mesti berpikir dan berprilaku seperti Kristus, memiliki karakter Kristus, sehingga pada akhirnya melahirkan generasi yang siap melayani Tuhan serta menjadi berkat bagi bangsa/generasi di zamannya.

Karena itu menurut Homrighausen, PAK adalah pendidikan yang berporos pada pribadi Yesus Kristus dengan menggunakan Alkitab sebagai dasar dan pedoman dalam pengajaran yaitu "pendidikan yang diberikan baik pada pelajar muda dan tua memasuki persekutuan iman yang hidup dengan Tuhan sendiri dan oleh serta dalam dia, mereka terhisap pada persekutuan jemaat-Nya yang mengakui dan memuliakan namaNya di segala waktu dan tempat.

Menurut Robert R. Boehlke, PAK berfungsi untuk mengantar pembelajar mendapatkan pendidikan secara utuh, hal tersebut membuat si pelajar mendapatkan pengalaman yang benar tentang Allah Bapa di dalam Tuhan Yesus Kristus. ${ }^{2}$ Melalui Pendidikan Agama Kristen, pengalaman yang benar bersama Tuhan Yesus Kristus

\footnotetext{
${ }^{1}$ Homrigausen E.G dan I.H. Enklaar, Pendidikan Agama Kristen (Jakarta: BPK Gunung Mulia, 2011),19-24

${ }^{2}$ Robert R. Boehlke, Sejarah Perkembangan dan Praktek PAK: dari Yohanes Amos Comenius hingga Perkembangan PAK di Indonesia. (Jakarta: BPK-Gunung Mulia, 2011), 691-692
}

akan terbangun, tugas mulia tersebut merupakan perintah yang diamanatkan Tuhan Yesus dalam Matius 28:18-20.

Jadi PAK merupakan pendidikan yang berpusat pada Tuhan Yesus Kristus, dasar pendomannya pada Alkitab yang menjadi tulang punggung dalam membangun generasi yang berkarakter.

Selanjutnya perlu ditegaskan bahwa hal mendasar yang membedakan antara PAK dan pendidikan umum terletak pada kuasa Roh Kudus yang membimbing dan menumbuhkan pribadi yang berkarakter untuk mengenal kehendak Allah. Dalam hal ini melalui PAK karakter pribadi seseorang dibangun untuk mengenal Allah dalam Tuhan Yesus untuk mengalami pengalaman yang benar dengan Allah.

Dengan kata lain PAK merupakan pendidikan yang ikut membentuk watak atau karakter, atas kuasa Roh Kudus menerima serta mengakui Yesus Kristus sebagai Tuhan dan Juruselamatnya secara pribadi, yang menyelamatkan dan menebus umat manusia dari hukuman dosa (Yoh. 3:16; Rom. 10:9; Rom. 5:8-10; 1 Yoh. 5:13-15).

Pendidikan Kristen adalah memuridkan, menggerakkan anak-anak dekat dengan Tuhan. Mendidik anak dalam Kristus adalah mendidik dalam kepemimpinan yang spiritual. Henry $\mathrm{T}$. Blackaby dan Richard Blackaby dalam spiritual leadership menyatakan bahwa Spiritual leadership adalah proses menggerakkan orang-orang dalam agenda Tuhan (moving people on the God's agenda). Nicholas Wolterstorff, seorang ahli pendidikan Kristen yang merupakan profesor teologi dari Yale University pernah menyatakan bahwa manusia merupakan manusia yang membutuhkan pendidikan supaya dapat bertahan hidup. Para 
pendidik Kristen harus berfokus pada Allah sebagai pusat dari segala hal dalam mendidik karena Alkitab dengan tegas menyatakan "sebab di dalam Dialah tersembunyi segala harta hikmat dan pengetahuan" (Kol. 2:3). ${ }^{3}$

Dalam tulisan ini penulis hendak mengenalkan tentang temperamen dasar dari Abraham, Musa, Petrus dan Paulus, dimana hal ini dapat menjadi pendorong bagi peserta didik untuk menjadi pribadi yang tangguh sehingga dapat menjadi pedoman untuk merefleksikan panggilan hidupnya.

Tuhan memanggil Abraham dengan temperamen Flegmatik, keluar dari negeri Ur ke negeri yang akan ditunjukkan Allah, awalnya enggan namun akhirnya dia rela meninggalkan negeri leluhurnya yang sudah mengikat sekian lama, semata-mata karena responsnya kepada Allah. Abraham setia dan taat pada pimpinan Allah sepanjang hidupnya, dikenal sebagai bapa orang beriman, juga mendapat sebutan sebagai sahabat Allah (Yak. 2:23), Allah memakai Abraham untuk menjadi Bapa dari bangsa yang dipilih Allah yaitu Israel. ${ }^{4}$ Tuhan memanggil Musa dengan temperamen Melankolik, mengambil ciri khas temperamen Musa, disamping kepribadian dan bakatnya, ia seorang yang setia, lembut hati, sabar, ketika ia bersedia taat dan patuh untuk menyelamatkan bangsa Yahudi. ${ }^{5}$ Tuhan memanggil Petrus

\footnotetext{
${ }^{3}$ Khoe Yao Tung, Terpanggil Menjadi Pendidik Kristen (Yogyakarta: Andi, 2016) 2

4 Lahaye, Tim, Hubungan Temperamen dan Karunia Rohani, (Jakarta: Yayasan Media Buana Indonesia, 1999), 43, Lahaye, Tim. Temperamen yang Diubahkan, (Surabaya: Yakin, 1981),153, 164166

${ }^{5}$ Ibid, 39, 126-132,150
}

dengan temperamen Sanguin, merupakan salah satu rasul yang terkemuka dalam pemberitaan keselamatan yang mula-mula. Petrus yang latar belakang hidupnya di alam bebas, sebagai nelayan, ia memiliki ketidakstabilan emosi. Sederetan peristiwa dialaminya, terkadang terlalu berani, terkadang terlalu penakut, pernah menyangkal Yesus, namun ketika sudah menerima pengampunan, dia berubah menjadi rasul yang teguh dan menjadi saksi Kristus. ${ }^{6}$

Tuhan memanggil Paulus dengan temperamen bawaannya Kolerik, orang yang berkemauan keras, kontroversiil dan mengalami pertobatan, sifatnya pemberani mampu berperan dalam pertumbuhan gereja. $^{7}$

\section{Tinjauan Teoritis}

\section{Temperamen}

Temperamen dapat dirumuskan sebagai suasana hati yang mencerminkan kehidupan emosional seseorang. Karena itu hingga tahap tertentu masing-masing manusia mempunyai kisaran emosi sendirisendiri, temperamen sendiri merupakan bahwaan sejak lahir, bagian dari undian genetik yang memiliki kekuatan hebat dalam bentang kehidupan ini. Jerome Kagan, ahli psikologi perkembangan yang terkemuka di Harvard University beranggapan bahwa sekurang-kurangnya ada empat jenis temperamen, yaitu penakut, pemberani, periang dan pemurung, dan masing-masing disebabkan

\footnotetext{
${ }^{6}$ Ibid, 30, 53-59

${ }^{7}$ Ibid, 35, 84,101,103
} 
oleh pola kegiatan otak yang berbedabeda. $^{8}$

Temperamen adalah merupakan aspek kejiwaan daripada kepribadian, dipengaruhi oleh kondisi jasmaniah yang dibawa sejak lahir, oleh karenanya sukar diubah oleh pengaruh dari luar. 9 Temperamen dan kepribadian kadang dianggap sama karena beruhubungan erat, walaupun diantara keduanya sebenarnya memiliki perbedaan. Temperamen lebih berhubungan dengan faktor-faktor biologis dan fisiologis yang sedikit sekali mengalami perubahan dalam per-kembangannya. Sedangkan kepribadian memiliki kemungkinan untuk berubah dalam perkembangan individu karena berhubungan dengan faktor-faktor lingkungan. ${ }^{10}$

Temperamen seseoranglah yang menjadikan ia ramah tamah atau ekstrovert dan pemalu atau introvert. Hal ini dapat ditemui pada dua orang semacam itu meskipun lahir dari rahim orangtua yang sama. Demikian pula, temperamen dapat membuat beberapa orang bersikap antusias terhadap seni dan musik, sementara yang lain menyukai olah raga atau industri. Meskipun bukan hanya temperamen yang mempengaruhi tingkah laku seseorang, namun temperamen memiliki pengaruh utama dalam kehidupan seseorang. ${ }^{11}$

\footnotetext{
8 Goleman, Daniel, Kecerdasan Emosional: Temperamen bukanlah Suratan Takdir. (Jakatra: Gramedia Pustaka, 2000), 305-306

9 Stanley Heath, Psikologi yang Sebenarnya (Yogyakarta. Yayasan Andi, 1999), 60

10 https://www.dictio.id/t/apa-yang-dimaksuddengan-temperamen-manusia/8861.Diunduh 12 April 2018

${ }^{11}$ Lahaye, Tim, Hubungan antara Temperamen dan Karunia Rohani (Jakarta: Metanoia), 1999,114-16
}

Temperamen merupakan kombinasi dari sifat-sifat bawaan sejak lahir, terdapat empat macam temperamen yaitu Sanguin, Kolerik, Melankolis dan Plegmatis, masing masing memiliki kelemahan dan kelebihan. Temperamen merupakan bahan dasar yang membentuk watak dan kepribadian manusia, masing-masing memiliki keunikan, satu dengan yang lain berbeda secara mendasar, baik dalam pikiran, perasaan maupun keinginan. ${ }^{12}$

Temperamen (perangai) adalah kombinasi pembawaan yang diwarisi dari orang tua. Tidak ada yang lebih mempengaruhi perilaku manusia, dibandingkan dengan temperamen yang diwarisi. Kombinasi gen dan kromosom ke dua orang tua pada waktu pembuahan menentukan temperamen dasar manusia 9 bulan sebelum manusia menarik napas untuk pertama kalinya. Kombinasi inilah yang banyak bertanggungjawab terhadap tindakan reaksi, dan respons-respons emosional manusia. ${ }^{13}$

Telaah Immanuel Kant (1724-1804) tentang temperamen-temperamen memiliki sifat-sifat khas sebagai berikut: ${ }^{14}$ Pertama Temperamen sanguinis (orang dengan darah ringan). Temperamen ini ditandai oleh sifat mudah dan kuat menerima kesan (pengaruh kejiwaan), tetapi yang tidak mendalam dan tidak tahan lama. Kedua, Temperamen melancholis (orang dengan darah berat), sifat khas temperamen ini ialah: semua hal yang bersangkutan dengan

\footnotetext{
12 Stanley Heath, Psikologi yang Sebenarnya (Yogyakarta. Yayasan Andi, 1999), 142-143

${ }^{13}$ Kirsey, David, Please Understand Me II (USA: Prometheus Nomines Books Company, 1998), 2022

14 Suryabrata, Sumadi, Psikologi Kepribadian, (Jakarta: Raja Grafindo Persada, 2015), 57.
} 
dirinya dipandangnya penting dan selalu disertai dengan syakwasangka atau kebimbangan; perhatiannya terutama tertuju kepada segi kesukaran-kesukarannya. Ketiga, Temperamen choleris (orang dengan darah panas). Sifat khas golongan tenperamen ini ialah: lekas terbakar tetapi juga lekas padam atau tenang, tanpa membenci; tindakan-tindakannya cepat, tetapi tidak constant. Keempat, Temperamen phlegmatic (orang dengan darah dingin). Sifat khas golongan temperamen ini ialah: lambat menjadi panas, lambat untuk marah, cocok untuk tugas-tugas ilmiah.

Intisari teori temperamen pada mulanya diciptakan oleh Hipocrates, lebih dari duaribu empat ratus tahun yang lampau, yang membagi manusia menjadi empat golongan dasar, yaitu: Sanguinis, Kholeris, Melankolis dan Phlegmatis, dengan kekuatan dan kelemahan sebagai berikut: ${ }^{15}$

Temperamen Sanguinis. Kekuatan: Ramah, Responsif, Hangat dan bersahabat, Banyak bicara, Antusias, dan Berbelas Kasih. Kelemahan:Tidak disiplin, Emosi tidak stabil, Tidak produktif, Egosentris, dan Membesar-besarkan masalah.

Temperamen Kholeris. Kekuatan: Berkemauan keras, Independen, Memiliki visi, Praktis, Produktif, Tegas, dan Pemimpin. Kelemahan: Dingin dan tidak emosional, Merasa puas diri, Ceroboh, Dominan, Sulit mengampuni, Sarkastik, Pemarah dan Kejam.

Temperamen Melankolis. Kekuatan: Berbakat, Analitis, Estelitis, Rela Berkorban, Tekun dan Disiplin. Kelemahan

\footnotetext{
${ }^{15}$ Lahaye, Tim, Hubungan antara Temperamen dan Karunia Rohani (Jakarta: Yayasan Media Buana Indonesia, 1999), 7, 22
}

Pemurung, Berpusat kepada diri sendiri, Suka menyiksa, Pembalas, Perasa, Kurang bermasyarakat dan Berpikir negative.

Temperamen Phlegmatis. Kekuatan: Tenang, kalem, Cuek/tidak peduli, Dapat diandalkan, Diplomatis, Efisien, teratur, dan Praktis, humoris. Kelemahan Tidak punya motivasi, Suka menunda-nunda, Egois, Kikir, Menyelamatkan diri sendiri, Tidak tegas, Penakut dan Suka kuatir,

Keempat temperamen tersebut menarik bagi orang-orang Kristen disebabkan karena begitu bersesuaian dengan konsepkonsep Alkitabiah. Seperti Alkitab ajarkan bahwa semua orang memiliki kelemahan masing-masing temperamen. Alkitab berkata bahwa manusia memiliki "alam lama" yang bersifat kedagingan". Temperamen terbentuk dari watak-watak sejak lahir, beberapa diantaranya adalah kelemahankelemahan.

Penggolongan keempat temperamen memang tidak diajarkan secara tegas didalam Alkitab, tapi keempat pendalaman riwayat hidup dari pribadi-pribadi di Alkitab akan memperlihatkan kekuatankekuatan dan kelemahan-kelemahan masing-masing temperamen. ${ }^{16}$

\section{Temperamen Dasar Abraham, Musa, Petrus dan Paulus}

Abraham memiliki temperamen dasar flegmatik, kekuatannya adalah seorang yang memiliki karakter tenang, damai dan baik hati. Tempramen flegmatik lebih stabil di antara semua temperamen yang ada. Abraham seorang yang setia, pen-

\footnotetext{
${ }^{16}$ Florence Littaeur, Kepribadian Plus. Pohon Kepribadian Anda. (Jakarta: Binarupa Aksara, 1997), .44
} 
dengar yang baik dan bisa mempunyai humor yang menyenangkan. Ia bekerja tanpa adanya suatu tekanan, rapi dan tetap teguh dalam mempertahankan apa yang telah menjadi peraturan. Ia sangat berhatihati di dalam mengambil tindakan. Dalam Kitab Kejadian 22 menjelaskan "Allah mencoba Abraham" dan Abraham berhasil menjalankannya, karena imannya. ${ }^{17} \mathrm{Ke}-$ kuatan orang Flegmatik adalah menjaga kedamaian, seperti dalam Mazmur 4:9 "Maka aku terbaring dan tidur dengan tenteram, sebab hanya engkau, Tuhan membuat hidupku aman. ${ }^{18}$ Kelemahannya Abraham ketika masih bernama Abram, pada saat pertama kali muncul di Alkitab, ketakutan mewarnai segala sesuatu yang ia lakukan pada masa mudanya. Sebagai contoh, ia merasa enggan untuk meninggalkan zona rasa aman yaitu kota Ur. ${ }^{19}$

Dalam Kejadian 12:1-7, perasaan khawatir tampak pada seseorang yang dominan Flegmatik, yang menjadi masalah adalah orang Flegmatik, cenderung senang kemapanan, tidak senang melawan perubahan. Orang Flegmatik hampir tidak pernah marah, mengalami tekanan jiwa, sering menunjukkan gejala tidak antusias, diam-diam merasa khawatir dan tidak bisa mengambil keputusan. ${ }^{20}$

17 Lahaye, Tim, Temperamen yang Diubahkan (Surabaya, Yakin, 1981), 153-175

${ }^{18}$ Littaeur, Florence, Kepribadian Plus. Pohon Kepribadian Anda (Jakarta: Binarupa Aksara, 1997), 73

19 Layahe, Tim, Hubungan Temperamen dan Karunia Rohani, (Jakarta: Yayasan Media Buana Indonesia, 1999), 43

${ }^{20}$ Littaeur, Florence. Bagaimana Memahami Orang Lain dan Memahami Diri Sendiri, (Jakarta: Bina Rupa Aksara, 1977), 234
Musa temperamen bawaannya adalah Melankolik. ${ }^{21}$ Kekuatan Musa, Orangorang Melankolik yang termasuk "golongan termasyur" selain Musa ialah Yakob, Salomo, Elia, Yesaya, Daniel, Yehezkiel, Obaja, Yunus, Yohanes Pembabtis, Rasul Yohanes dan Thomas, serta masih banyak yang lain, yang terkemuka adalah Musa. ${ }^{22}$

Setiap kata dari Pentateukh yang ada sekarang berasal dari Musa (Kel. 17:14; 24:5-7), Bilangan 33:2; Ulangan 31:9; Yosua 23:6; Lukas 24:27,44; Yehezkiel 1:17; 5:46). Kepemimpinannya dan kesetiaannya pada visi untuk membawa bangsa Israel keluar dari Mesir menuju tanah perjanjian adalah menunjukkan bahwa Musa disamping Melankolik. Sifatnya adalah Kolerik. Musa memperoleh pengetahuan membaca dan menulis heeroglif, yaitu abjad Mesir kuno, sehingga mampu menyalin naskah-naska, menulis dengan sangat indah, serta mengerjakan tata administrasi. ${ }^{23}$ Kelemahan Musa: Pada waktu ia berumur empatpuluh tahun, timbullah keinginan dalam hatinya untuk mengunjungi saudara-saudaranya, yaitu orang-orang Israel (Kisah 7:23). Tanpa menyadarinya, Musa memasuki posisi yang rawan, Musa tahu akan membebaskan bangsa Israel. Kecemasan, ketidaksabaran, meluncurkan serangan gegabah, seperti ctatan dalam Keluaran 2:11 "lalu dilihatnyalah seorang Mesir memukul se-

\footnotetext{
21 Lahaye, Tim. Temperamen yang Diubahkan, (Surabaya, Yakin, 1981), 84

${ }^{22}$ Lahaye, Tim, Temperamen yang Diubahkan., (Surabaya: Yakin, 1981), 126-152

23 Douglas.J.D \& Hillyer, N (penyunting), Ensiklopedi Alkitab Masa Kini Jilid 1, (Jakarta: Yayasan Bina Kasih, 1992), 103
} 
orang Ibrani, seorang dari saudara-saudaranya itu ${ }^{24}$

Musa kehilangan hubungan dengan Allah. Lalu melarikan diri dan menyeberangi padang pasir yang terletak antara dirinya dengan batas timur; menyusuri gunung melewati semenanjung Sinai, setelah tahun-tahun ia memimpin orang-orangnya; akhirnya ia duduk dengan letih di tepi sumur tanah Midian. Musa lari ke Midian (Kel.2:15), disana ia bertemu Zipora anak Imam Yitro, lahirlah Gersom (Kel. 2:16-22). Ketika Musa sedang menggembalakan kawanan domba Yitro, mertuanya, di Tanah Midian, ia melihat semak duri yang menyala, tetapi tidak hangus terbakar. Di Midian, juga menunukkan salah satu perbuatan pertama yang dilakukan adalah ikut campur tangan ketika sekelompok gembala sedang mengusik beberapa wanita di sebuah sumur di padang gurun (Lihat Kel. 2:16-29). ${ }^{25}$

Kelemahan berikutnya yang ditunjukkan Musa yaitu amarah. Temperamen Melankolis memiliki kekhususan dalam kelemahan emosionalnya, terutama kecenderungannya menjadi marah dan menderita depresi. Beberapa jenius terhebat di dunia ini merupakan para melankolik berbakat yang membuangbuang talenta mereka, karena ngambek, menjadi apatis dan tidak produktif. ${ }^{26}$

\footnotetext{
${ }^{24}$ Swindoll, Charles. Moses: A Man of Selfless Dedication. (Dallas, Texas: World Publishing, 1999), 68-69.

${ }^{25}$ Getz, Gene A. When You Feel like You haven't got it (California: Regal Books, 1999), 60-77

${ }^{26}$ Lahaye, Tim; Philip; Bob, Anger Is A Choice (Zondervan Publishing Company, 1998), .147-149
}

Petrus memiliki kombinasi temperamen Sanguin Kolerik. ${ }^{27}$ Petrus dalam terjemahan Yunani berasal dari kata Aram, Kefas, artinya padas. ${ }^{28}$ Kekuatan Petrus dengan temperamen Sanguin, adalah ramah, terbuka, menarik, dermawan dan penuh belas kasihan, penuh tanggap terhadap keadaan sekitarnya, pribadi yang berkharisma. Sifat Petrus yang tanggap, ketika beberapa perempuan melaporkan makam Yesus sudah kosong (Mat. 28:6), Petrus berlari cepat menuju makam. ${ }^{29}$

Petrus juga memiliki kekuatan sebagai pribadi yang tegas,efektif dan produktif. ${ }^{30}$ Kelemahannya Petrus adalah kemauannya lemah, tidak mantap, perasaannya meletup-letup/impulsif, tidak tenang dan mementingkan diri sendiri, sebagaimana dicatat dalam Matius 19:27: "Kami telah meninggalkan segala sesuatu dan mengikut Engkau, jadi apakah yang akan kami peroleh?. ${ }^{31}$ Petrus juga memiliki kelemahan seorang sering berbicara dan sebagian besar yang diucapkan salah, sifatnya angkuh, berkemauan lemah dan dangkal, melakukan penyangkalan sebagaimana yang dicatat dalam Matius 26: 69-70 "Engkau juga selalu bersama dengan Yesus, orang Galilea itu! "Tetapi ia me-

\footnotetext{
${ }^{27}$ Lahaye, Tim. Hubungan antara Temperamen dan Karunia Rohani (Jakarta: Yayasan Media Buana Indonesia, 1999), 30

${ }^{28}$ Haag, Hebert, Kamus Alkitab. Lembaga Biblika Indonesia (Jakarta. Nusa Indah: Lembaga Biblika Indonesia, 1980), 53.

29 Lahaye, Tim, Temperamen yang diubahkan, (Surabaya: Yakin, 1981), 35-37

${ }^{30}$ Lahaye, Tim, Hubungan antara Temperamen dan Karunia Rohani, (Jakarta: Yayasan Media Buana Indonesia, 1999), 30

31 Lahaye, Tim, Temperamen yang diubahkan, (Surabaya: Yakin, 1981), 37-42
} 
nyangkalnya didepan semua orang, katanya

"Aku tidak tahu apa yang kau maksud. ${ }^{32}$

Paulus memiliki temperamen bawaannya Kolerik. ${ }^{33}$ Kekuatan Paulus yaitu disiplin, berkemauan keras, pemimpin bervisi, dinamis, pemberani dan motivasi tinggi. Dalam 1 Korintus 9:24-27, Paulus menegaskan patokan-patokan dari disiplin pribadi. Dalam Kisah Para Rasul 13. Kisah Para Rasul 22, dalam 2 Korintus 11, dan Kisah 14:19-21. Paulus tetap bersemangat, memiliki motivasi yang tinggi, rahasia motivasi Paulus adalah berasal dari Roh Kudus, seperti Filipi 3:1314 Paulus mengakui bahwa meskipun ia tidak sempurna, ia telah belajar melakukan satu hal: "Aku melupakan apa yang telah terjadi di belakangku dan mengarahkan diri kepada apa yang dihadapanku, dan berlarilari kepada tujuan untuk memperoleh hadiah, yaitu panggilan sorgawi dari Allah dalam Kristus Yesus". ${ }^{34}$

Kelemahan Paulus, Paulus yang fanatik memiliki kelemahan yang menonjol yaitu sifatnya yang kejam dan pemarah sehingga mudah tersinggung, cepat untuk menilai cenderung bermusuhan. Sebelum bertemu Tuhan Yesus, ia seorang penganiaya gerakan Kristen mula-mula, namun setelah bertemu dengan Tuhan Yesus, maka sifat-sifat positifnya yang menonjol, melalui ketajaman intuisinya, dapat merombak model primordialisme yang berlaku bagi kalangan Yudaisme. Kisah 23 kemarahan Paulus nampak setelah ditangkap di depan Mahkamah Sanhedrin. ${ }^{35}$

\footnotetext{
${ }^{32}$ Lahaye, Tim, Hubungan antara Temperamen dan Karunia Rohani, (Jakarta: Yayasan Media Buana Indonesia, 1999), 32

${ }^{33}$ Ibid 35

${ }^{34}$ Lahaye, Tim, Temperamen yang diubahkan, (Surabaya: Yakin, 1981), 97-112

${ }^{35}$ Ibid 128
}

\section{Metode Penelitian}

Metode penelitian ini adalah kualitatif. Menurut Sugiyono, metode penelitian kualitatif adalah metode penelitian yang digunakan untuk meneliti kondisi objek yang alamiah, (sebagai lawannya adalah eksperimen). Dalam penelitian kualitatif, peneliti adalah sebagai instrumen kunci, teknik pengumpulan data dilakukan secara trianggulasi (gabungan), analisi data bersifat induktif, dan hasil penelitian kualitatif lebih menekankan makna dari pada generalisasi.

Dalam penelitian kualitatif mengkaji perspektif partisipan dengan strategistrategi yang bersifat interaktif dan fleksibel. Penelitian kualitatif ditujukan untuk memahami fenomena-fenomena sosial dari sudut pandang partisipan. Dengan demikian arti atau pengertian penelitian kualitatif tersebut adalah penelitian yang digunakan untuk meneliti pada kondisi objek alamiah dimana peneliti merupakan instrumen kunci. ${ }^{36}$

Teknik pengumpulan data yang digunakan dalam penelitian ini adalah studi pustaka, yaitu cara yang dipakai untuk menghimpun data-data atau sumbersumber yang berhubungan dengan topik yang diangkat dalam suatu penelitian. Studi pustaka ini dapat diperoleh dari berbagai sumber, yaitu: jurnal, buku, dokumentasi, dan internet.

\footnotetext{
36 Sugiyono, Memahami Penelitian Kualitatif, (Bandung : Alfabeta, 2005), 1, 21
} 


\section{Analisa Temperamen Dasar Abraham, Musa, Petrus dan Paulus}

\section{Abraham}

Abraham sebelumnya bernama Abram (Ibrani: Ibrani: אֵָבְרָם 'AV'RAM), dia dijanjikan akan menjadi bapa sejumlah besar bangsa. Sebagai pertanda dari hal ini namanya diubah dari Abram, "bapa yang luhur", menjadi Abraham (Ibrani: אָבְרָרָָם 'AV'RAHAM) yang artinya adalah: "bapa sejumlah besar bangsa". ${ }^{37}$ Abraham adalah putra Terah dan keturunan Sem, leluhur bangsa Yahudi dan bangsa-bangsa lain. Sesuai janji dalam perjanjian suci antara Allah dengan Abraham dan keturunannya turun temurun, namanya diganti menjadi Abraham (a"vraham) yang berarti "bapak sejumlah bangsa" (Kej. 17:5). ${ }^{38}$

Abraham menunjukkan kehidupan yang beriman. Ia merupakan contoh terbaik dari iman yang hidup. Ia senantiasa berharap kepada pimpinan Allah, percaya akan janji-janji Allah, mewarisi pem-berkatan Allah, mengalami ujian-ujian serba berat, kendati terkadang jatuh, tetapi dibenarkan oleh karena iman (Kej. 15:6), serta disebut sahabat Allah (Yak. 2:23). ${ }^{39}$

Imannya hidup, kesalehan yang sejati, saat dipanggil untuk meninggalkan rumah dan negaranya, untuk mengorbankan anaknya, taat sepenuhnya dan mendengarkan perintah-Nya. Ujian yang di-

37 http://www.sarapanpagi.org/abraham-vt37.html diunduh 10 Mei 2014

${ }^{38}$ Hartanti, Mary , Biodata Tokoh-tokoh Alkitab Perjanjian Lama, Arti, Nama dan Profesinya, Jakarta, 1974), Markus Agung: 22

${ }^{39}$ Baxter, Sidlow. J, Menggali Isi Alkitab Buku 1 Kejadian sd Ester, (Jakarta:Yayasan Komunikasi Bina Kasih/OMF, 2009), 53 hadapinya luar biasa besar. Abraham siap mempersembahkan Ishak anaknya sesuai perintah Tuhan. Menjadi bukti dari sebuah iman yang penuh dan hidup, iman yang disertai perbuatan (Yakobus 2:14). Kejadian 12:7. "Ketika itu TUHAN menampakkan diri kepada Abram dan berfirman: "Aku akan memberikan negeri ini kepada keturunanmu." Maka didirikannya di situ mezbah bagi TUHAN yang telah menampakkan diri kepadanya. Kejadian 13:17, Abraham taat dan sangat percaya dengan perintah Tuhan. ${ }^{40}$

Abraham memiliki kekuatan taat, Abraham lulus dalam ujian atas iman. Abraham adalah seorang yang taat, mentaati perintah Allah tanpa syarat. Ketaatan merupakan bagian diri Abraham. Disini ditemukan bahwa tanpa pertanyaan Abraham menjalankan apa yang diperintahkan Allah, untuk mempersembahkan Ishak anak yang tunggal yang dikasihinya, inilah karakteristik ketaatan. Abraham telah memberikan pelajaran melalui kekuatan serta kelemahan temperamen flegmatik, dan hidup yang telah berubah dengan berserah penuh kepada Allah untuk menjalankan hidup sesuai rencana Allah. ${ }^{41}$ Merupakan seorang pemikir dan perencana, berbakat menjadi diplomat, pendamai, senang berunding daripada bertengkar. Paling mudah diajak bergaul dan secara alamiah orang yang paling menyenangkan diantara semua temperamen. Memandang kehidupan sebagai pengalaman yang menggembirakan, menyenangkan, sehingga mudah untuk bergaul dan me-

\footnotetext{
40 Lahaye, Tim, Temperamen yang Diubahkan, (Surabaya: Yakin, 1981), 153-174

${ }^{41}$ ibid
} 
miliki banyak teman, serta menjadi pendengar yang baik. ${ }^{42}$

Telaah Immanuel Kant (1724-1804) tentang temperamen flegmatik sifat-sifat khas Temperamen phlegmatik (orang dengan darah dingin). Sifat khas golongan temperamen ini ialah: lambat menjadi panas, lambat untuk marah, cocok untuk tugas-tugas ilmiah. ${ }^{43}$

Abraham dengan temperamen dasar Flegmatik, dipilih Allah untuk menjadi hambanya dengan segala kekuatan dan kelemahan dari temperamen dasar yang dimiliki. Allah memperlengkapi Abraham dengan kekuatannya yang menonjol yaitu iman, sehingga sanggup melaksanakan perintah Allah untuk keluar dari tempat asalnya ke negeri yang dijanikan Allah dan menjadi saksi Allah di tengah-tengah bangsa yang belum mengenal-Nya. Oleh karenanya dalam rancangan keselamatan berikutnya adalah berasal dari keturunan Abraham, bukan secara lahiriah, tetapi secara iman yang digenapi dalam Yesus Kristus. ${ }^{44}$

Seorang dengan temperamen Flegmatik adalah seorang yang tenang, damai, super introvert, rendah hati, santai, diam, tenang, tidak tergesa-gesa, tidak pernah merasa terganggu dengan titik didih yang tinggi, sehingga hampir tidak pernah marah. ${ }^{45}$ Makna yang dapat dipelajari dalam PAK adalah Allah memanggil Abraham Flegmatik dan ia tetap menjadi Abraham yang Flegmatik. Abraham

42 Littaeur, Florence,Teka Teki Kepribadian (Jakarta: Proffesional Books, 1997), 77-78

43 Suryabrata, Sumadi. Psikologi Kepribadian (Jakarta: Raja Grafindo Persada, 2015), 57.

${ }^{44}$ Lahaye, Tim, Temperamen yang Diubahkan, (Surabaya: Yakin, 1981), 153-174

45 http://c3i.sabda.org/temperamen_flegmatik diunduh 5 Mei 2014 dengan temperamen dasar Flegmatik, dipilih Allah untuk menjadi hambanya dengan segala kekuatan dan kelemahan dari temperamen dasar yang dimiliki. ${ }^{46}$

Musa

Kisah Musa di Keluaran 2:10, Ketika anak itu telah besar, dibawanyalah kepada puteri Firaun, yang mengangkatnya menjadi anaknya, dan menamainya Musa, sebab katanya: "Karena aku telah

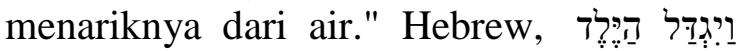

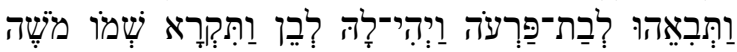

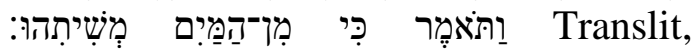
VAYIG'DAL HAYELED VATEVI'EHU LEVAT-PAR'OH VAYEHI-LAH LEVEN VATIQ'RA SYEMO MOSYEH VATOMER KI MIN-HAMAYIM MESYITIHU. Di dalam seluruh Kitab Taurat, ia disebut sebagai "Musa" ( מששֶה MOSHEH/ MOSYEH), dan Allah sendiri memanggilnya dengan nama "Musa"47

Musa seorang nabi yang dipakai Allah, Ulangan 34:10 mencatat "seperti Musa yang dikenal Tuhan dengan berhadapan muka, tidak ada lagi nabi yang bangkit diantara orang Israel." Karena perlindungan Tuhan, Musa luput dari pembunuhan yang dicanangkan oleh Firaun, agar semua bayi-bayi laki-laki Ibrani dibunuh, bahkan diangkat dan diselamatkan oleh Puteri Firaun sendiri yang mengambilnya dari air. Musa mendapat kesempatan dididik dalam berbagai pengetahuan dan hikmat orang Mesir di-

\footnotetext{
46 Lahaye, Tim, Temperamen yang Diubahkan, (Surabaya: Yakin, 1981), 153-174

47 http://www.sarapanpagi.org/musa-vt263.html. Diunduh 15 Januari 2014.
} 
bawah pengawasan guru-guru yang cerdik. Namun setelah dewasa, ia menolak disebut anak Puteri Firaun, karena ia lebih suka menderita sengsara dengan umat Allah daripada menikmati kesenangan yang bersifat sementara. ${ }^{48}$

$$
\text { Musa dengan temperamen }
$$

Melankolik sesuai dengan kelebihannya memiliki kejeniusan, kreativitas dan bakat kepekaan tinggi. Seorang pemikir dan analitis, sangat menghargai karya-karya musik, sastra, seni, namun kelemahannya sulit mengambil sebuah keputusan. Oleh karena perfeksionis maka sering mengalami kemurungan apabila apa yang dikerjakan tidak sesuai dengan standarnya, ragu-ragu, mudah stres dan berlanjut pada depresi. ${ }^{49}$

Charles Swindoll dalam bukunya Moses: A Man of Selfness Dedication menunjukkan Musa seorang pangeran Mesir yang terbiasa hidup nyaman, bersedia tinggal bersama keluarga Imam dari Midian seperti yang dicatat di Keluaran 12:16-21. Musa rela untuk menjadi orang tidak terkenal, untuk tinggal terpisah dari gemerlapnya cahaya untuk menerima statusnya yang baru. ${ }^{50}$ Menurut C.E.Macartney, Musa mengambil keputusan tersebut ketika masih di dalam istana Firaun. ${ }^{51}$

\footnotetext{
${ }^{48}$ Von Rad, Musa. (Jakarta: BPK Gunung Mulia, 1973) 12-26; Harrison, R.K Introduction to The Old Testament, Grand Rapids, Michigan, Eederman's Publishing Company, 1977), 73

${ }^{49}$ Kirsey, David, Please Understand Me II, (USA: Prometheus Nomines Books Company, 1998), 19.

${ }^{50}$ Swindoll, Charles, Moses: A Man of Selfness Dedication. (Dallas, Texas: World Publishing, 1999), 213-215

${ }^{51}$ Macartney.C.E, Trial of Great Men of the Bible (New York: Abington, 1969), 59-62
}

Musa memperoleh pengetahuan membaca dan menulis hieroglif (abjad Mesir kuno), sehingga mampu menyalin maskah-naskah, menulis dengan sangat indah, serta mampu mengerjakan administrasi. ${ }^{52}$ Tulisan Musa dalam Ulangan 30-32 memberikan ide-ide penting untuk memahami hakikat dari Pendidikan Agama Kristen. Yesus sendiri berulang kali mengutip dari kitab Ulangan ketika dicobai di padang gurun. Di padang belantara pendidikan masa kini yang banyak diwarnai oleh macam-macam filosofi pendidikan. Ulangan 30:11, 31:9-13 dan 31:30 -32:4. Pendidikan yang digambarkan dalam ketiga perikop menghasilkan buah sepenuhnya dalam kehidupan Yesus Kristus. ${ }^{53}$

Makna yang dapat dipelajari dalam Pendidikan Agama Kristen adalah Allah memanggil Musa melankolik dan ia tetap menjadi Musa yang melankolik. Musa dengan temperamen dasar Melankolik, dipilih Allah untuk menjadi hambanya dengan segala kekuatan dan kelemahan dari temperamen dasar yang dimiliki. ${ }^{54}$

\section{Petrus}

Petrus, (Yunani: $\pi \varepsilon \tau \rho o \varsigma-$ petros). Ia juga memiliki nama Ibrani "SIMEON"

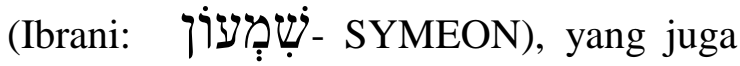
disebut "SIMON" (Yunani: $\sigma v \mu \varepsilon \omega v \quad-$ sumeôn). Ia juga disebut dalam nama

\footnotetext{
52 Douglas. J.D. \& Hillyer, $\mathrm{N}$ (penyunting), Ensiklopedi Alkitab Masa Kini. Jilid 1, (Jakarta: Yayasan Bina Kasih, 1992), 103

${ }^{53}$ Robert Pazmino, Fondasi Pendidikan Kristen. (Jakarta: BPK Gunung Mulia, 2012), 23

${ }^{54}$ Lahaye, Tim, Temperamen yang Diubahkan, (Surabaya: Yakin, 1981), 126-137
} 


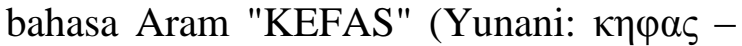
kêphas. ${ }^{55}$ Petrus dalam terjemahan Yunani berasal dari kata Aram, Kefas, artinya padas. ${ }^{56}$

Petrus nama aslinya Simon bin Yunus, lahir di Bethsaida, saudara Santo Andreas, keduanya bekerja sebagai nelayan. Oleh Yesus dinamakan Kefas (bahasa Aram) atau Petrus (transliterasi dalam bahasa Yunani) yang berarti batu karang, (Yoh. 1:42, Luk. 6:13-14, Mat. 16:18) yang menjadikannya pemimpin para Rasul dan kepala Gereja sebagai imamNya. Petrus menjadi saksi atas dibangkitkannya putri Yairus dari kematian (Markus 5:21-43), transfigurasi Yesus Kristus diatas bukit (Matius 17:1-8), serta sengsara Yesus di Taman Getsemani (Mat. 36-46). Ayahnya bernama Yunus (Mat. 16:17), ia berkeluarga (Mat. 8:14; Mark. 1:30), saudaranya Andreas (Yoh. 1:40). Menurut Injil Yohanes Bethsaida suatu kota di daerah Golan, penduduknya kebanyakan Yunani (Yoh. 1:44). Rumah Petrus ada juga di Kapernaum Galilea (Mark, 1:21). ${ }^{57}$

Petrus secara kepribadian mengalami pembentukan karakter yang baru, dimana sebutan sebagai baru karang menunjukkan kekokohan, kekuatan, keteguhan. Melalui pengalaman berinteraksi bersama Yesus Petrus telah mengalami perubahan nama dari Simon

55 http://www.sarapanpagi.org/petrus-vt4233.html. Diunduh 12 Maret 2014

${ }^{56}$ Haag, Hebert, Kamus Alkitab Lembaga Biblika Indonesia. (Jakarta. Nusa Indah: Lembaga Biblika Indonesia, 1980), 43

57 Douglas, J.D. \& Hillyer, N. (penyunting), Ensiklopedi Alkitab Masa Kini Jilid 1, (Jakarta: Yayasan Komunikasi Bina Kasih, 1992), 235; Hartati, Mary, Biodata Tokoh-Tokoh Perjanjian Baru, (Jakarta: Markus Agung, 1974), 80-90 memperoleh gelar baru yaitu Petrus. Secara empiris Petrus memberikan kontribusi pada pendefinisian karakter sesuai dengan fungsi, tugas serta tanggungjawab sebagai Rasul. Petrus menjadi saksi atas dibangkitkannya putri Yairus dari kematian, transfigurasi Yesus Kristus diatas bukit, serta sengsara Yesus di Taman Getsemani. ${ }^{58}$

Hal yang menarik dari Petrus, ia memahami bahwa kedudukan istimewa yang dimiliki oleh setiap orang percaya dalam Yesus Kristus sangat besar nilainya. Ia mendesak orang Kristen senantiasa menyadari pekerjaan Allah yang amat agung. Petrus memahami bahwa semakin sering mereka merenungkan status istimewa dalam Kristus, mereka semakin memeroleh kekuatan batiniah. ${ }^{59}$

Petrus adalah murid Yesus yg pertama dipanggil; ia selalu disebut yg pertama dalam urutan murid-murid; ia juga seorang dari ketiga murid yg merupakan kelompok akrabdengan Guru mereka (Markus 5:37; 9:2; 14:33; bnd 13:3). Tindakan pelayanannya yg didorong gelora hatinya, sering dilukiskan dalam Alkitab (bnd Matius 14:28; Markus 14:29; Lukas 5:8; Yohanes 21:7), dan dia bertindak sebagai jurubicara dari ke-12 murid itu (Matius 15:15; 18:21; Markus 1:36 dab; 8:29; 9: 5; 10:28; 11:21; 14:29 dab; Lukas $5: 5 ; 12: 41)$. Dalam saat penentuan dekat Kaisarea Filipi dialah jurubicara dari kelompok ke-12 murid: sebab pertanyaan itu ditujukan kepada mereka semua (Markus 8:27, 29), dan semua mereka

\footnotetext{
58 Lahaye, Tim, Temperamen yang Diubahkan, (Surabaya: Yakin, 1981), 35-78

59 BS. Sidjabat, Membangun Pribadi Unggul, (Yogyakarta. Andi., 2011), 137
} 
tergenggam satu dalam pandangan tertuju pada Yesus. ${ }^{60}$

Petrus dengan temperamen dasar Sanguin, adalah pandai menghangatkan suasana dengan kepandaiannya untuk bicara, sehingga banyak orang yang menyukai, namun kelemahannya adalah pada kestabilan emosi serta kurang disiplin dan kurang fokus pada prioritas serta kurang bertanggung jawab. Setelah melewati proses didikan dan berserah Yesus sang Guru Agung, Setelah pencurahan Roh Kudus (Kis. 2: 3-14). Petrus mengekspresikan kekuatan temperamen dasar Sanguinis, sehingga menjadi Rasul yang produktif, melakukan mujizat penyembuhan, pengkhotbah, juga pemimpin Gereja. Perubahan Petrus dari seorang dengan latar belakang nelayan, memiliki kemampuan menulis surat Petrus. Allah menjadikan Petrus untuk memberi gambaran kepada mahasiswa untuk hidup dekat dan bersandar kepada-Nya. ${ }^{61}$

Makna yang dapat dipelajari dalam PAK adalah Allah memanggil Petrus yang Sanguin, ia tetap menjadi Sanguin, setelah dipenuhi Roh Kudus, yang muncul adalah kekuatannya, yaitu diantaranya ramah dan pandai berbicara. Tuhan memperlengkapi Petrus sehingga memiliki kepandaian untuk berkhotbah, untuk mengukir sejarah berdirinya gereja mula-mula. Petrus dengan temperamen dasar Sanguin, dipilih Allah untuk menjadi hambanya dengan segala kekuatan dan kelemahan dari temperamen dasar yang dimiliki. ${ }^{62}$

\footnotetext{
60 http://www.sarapanpagi.org/petrus-vt4233.html. Diunduh 12 Maret 2014

61 Lahaye, Tim, Temperamen yang Diubahkan, (Surabaya: Yakin, 1981), 35-78

62 ibid Lahaye, Tim, Temperamen yang Diubahkan, (Surabaya: Yakin, 1981), 80-112
}

\section{Paulus}

Paulus dalam Kisah 13:9 disebut "Paulus" ( $\pi \alpha v \lambda$ os-PAULOS) adalah karena dia warganegara Romawi (Kisah 16:37; 22:25-29). Lihat Kisah 13:7: ada nama "Sergius Paulus", gubernur pulau Pafos, memberikan kita bukti bahwa Paulus adalah nama "Romawi" yang lazim. Dan karena ia juga berkomunitas pada orangorang yang berbahasa Yunani maka namanya juga dikenal sebagai "Saulus"

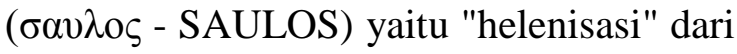

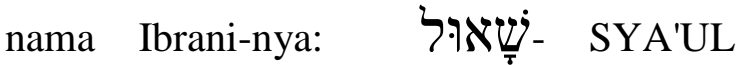
(bandingkan naskah Ha-Berit Ibrani). Rasul Paulus memiliki nama asli Ibrani "Saul" seperti nama moyangnya, raja pertama orang Israel (Kisah 13:21) dari suku Benyamin, dan nama "Paulus" (versi Romawi/ Latin), dan "Saulus" (versi Yunani). ${ }^{63}$

Paulus dengan temperamen dasar Kolerik yaitu cerdas, bersemangat, aktif, mempunyai kemauan keras, berani, pantang menyerah, mandiri serta berpikir praktis, pemimpin. Kepemimpinan yang diajarkan oleh Paulus berfokus pada karakter dan integritas seorang pemimpin. Paulus sangat berani menembus batas perbedaan atas adat, kebiasaan untuk menjadi pengikut Kristus. ${ }^{64}$

Paulus memberikan teladan sebagai pribadi yang disiplin, berkemauan keras, pemimpin bervisi, dinamis, pemberani dan motivasi tinggi. Dalam 1 Korintus 9:24-27, Paulus menegaskan patokan-patokan dari disiplin pribadi. Dalam Kisah Para Rasul 13. Kisah Para Rasul 22, dalam 2 Korintus

\footnotetext{
63 http://www.sarapanpagi.org/paulus-vt274.html. Diunduh 15 Januari 2015

${ }^{64}$ Lahaye, Tim, Temperamen yang Diubahkan, (Surabaya: Yakin, 1981), 80-112
} 
11, dan Kisah 14:19-21. Paulus tetap bersemangat, memiliki motivasi yang tinggi, rahasia motivasi Paulus adalah berasal dari Roh Kudus, seperti Filipi 3:13-14 Paulus mengakui bahwa meskipun ia tidak sempurna, ia telah belajar melakukan satu hal: "Aku melupakan apa yang telah terjadi di belakangku dan mengarahkan diri kepada apa yang dihadapanku, dan berlarilari kepada tujuan untuk memperoleh hadiah, yaitu panggilan sorgawi dari Allah dalam Kristus Yesus. Rasul Paulus memberikan banyak perhatian untuk membantu mengerti bahwa kepemimpinan yang sejati tidak berkenaan dengan kedudukan, kekuasaan, ketenaran, melainkan ketaatan status sebagai pelayan yang menghasilkan perubahan. ${ }^{65}$

Makna yang dapat dipelajari dalam Pendidikan Agama Kristen adalah Allah memanggil Paulus yang Kolerik, ia tetap menjadi Kolerik. Tuhan memperlengkapi Paulus yang memiliki ketajaman intuisi untuk melakukan pekerjaan Allah yang dahsyat. Paulus seorang Kolerik yang berani untuk keluar, memberitakan injil kepada bangsa-bangsa yang belum mengenal Allah. Surat-surat Paulus sejumlah empatbelas, mengungkapkan rahasia yang sangat dalam maknanya dalam mengikut Kristus dan menjadi hamba-Nya. Hasilnya menjalankan Amanat Agung dalam perspekrif lintas budaya, keberaniannya menembus batas tembok penyekat antar budaya dan bangsa, membuat Gereja dapat berdiri di seluruh bumi. Paulus dengan temperamen dasar Kolerik, dipilih Allah untuk menjadi hambanya dengan segala

\footnotetext{
65 http://sabda.org/publikasi/e-leadership/083 diunduh 16 Februari 2015.
}

kekuatan dan kelemahan dari temperamen dasar yang dimiliki. ${ }^{66}$

\section{Kesimpulan}

Abraham, Musa, Petrus dan Paulus telah memberikan pelajaran melalui gambaran temperamen Flegmatik, Melankolik, Sanguin dan Kolerik.

Dunia tempat kehidupan saat ini di penuhi dengan tantangan yang kompleks. Melalui pengenalan temperamen tersebut agar mampu mengatasi segala persoalan yang dihadapi di masa depan. Amsal 22:6 mengatakan "Didiklah orang muda menurut jalan yang patut baginya, maka pada masa tuapun ia tidak akan menyimpang dari pada jalan itu

Pembelajaran PAK melalui pengenalan temperamen dasar Abraham: Flegmatik; Musa: Melankolik; Petrus: Sanguin dan Paulus: Kolerik, dapat menjadi pendorong peserta untuk secara pribadi merefleksikan tujuan hidupnya sesuai dengan karakter temperamen dasar yang dimiliki. Dengan demikian, peserta didik dapat memahami bahwa hidup adalah sebuah karunia, apa yang dialami didalam kehidupannya adalah karunia Tuhan.

Kesadaran peserta didik akan peran dan fungsinya untuk hidup di dunia ini, hanya dapat diperoleh melalui pertolongan Roh Kudus. Hidup adalah pemberian, manusia adalah ciptaan Tuhan. Hidup adalah suatu rangkaian perubahan, dengan mengisi kesempatan dengan pola hidup yang bermakna, sehingga terjadi transformasi dan perubahan karakter menuju imagodei.

\footnotetext{
66 Lahaye, Tim, Temperamen yang Diubahkan, (Surabaya: Yakin, 1981), 80-112
} 


\section{Kepustakaan}

Alkitab, Jakarta: Lembaga Alkitab Indonesia, 2010.

Baxter, Sidlow. J. Menggali Isi Alkitab Buku 1 Kejadian sd Ester. Jakarta:Yayasan Komunikasi Bina Kasih/OMF, 2009.

BS. Sidjabat. Membangun Pribadi Unggul. Yogyakarta. Andi, 2011.

Daniel Haryono. Kamus Besar Bahasa Indonesia. Edisi Baru. Jakarta: Pustaka Phoenix, 2010.

Douglas. J.D. \& Hillyer, N (penyunting). Ensiklopedi Alkitab Masa Kini. Jilid 1. Jakarta: Yayasan Bina Kasih, 1992.

Getz, Gene A. When You Feel like You haven't got it. California: Regal Books, 1999.

Goleman, Daniel. Kecerdasan Emosional: Temperamen bukanlah Suratan Takdir. Jakatra: Gramedia Pustaka, 2000.

Haag, Hebert. Kamus Alkitab. Lembaga Biblika Indonesia. Jakarta. Nusa Indah: Lembaga Biblika Indonesia, 1980.

Harrison, R.K. Introduction to The Old Testament, Grand Rapids, Michigan, Eederman's Publishing Company), 1977.

Hartanti, Mary. Biodata Tokoh-tokoh Alkitab Perjanjian Lama, Arti, Nama dan Profesinya. Jakarta: Markus Agung, 1974

Homrigausen E.G dan I.H. Enklaar. Pendidikan Agama Kristen. Jakarta: BPK Gunung Mulia, 2011.

Kirsey, David. Please Understand Me II. Temperament Caracter Intelligence. USA: Prometheus Nomines Books Company, 1998.
Khoe Yao Tung, Terpanggil Menjadi Pendidik Kristen. Yogyakarta: Andi, 2016

Lahaye, Tim. Temperamen yang Diubahkan. Surabaya: Yakin, 1981

Lahaye, Tim; Philip, Bob. Anger Is a Choice. Zondervan Publishing Company, 1996.

Lahaye, Tim. Hubungan Temperamen dan Karunia Rohani. Jakarta: Yayasan Media Buana Indonesia, 1999.

Littaeur, Florence. Teka Teki Kepribadian. Jakarta: Proffesional Books, 1997.

Littaeur, Florence. Kepribadian Plus. Pohon Kepribadian Anda. Jakarta: Binarupa Aksara, 1997.

Littaeur, Florence. Bagaimana Memahami Orang Lain dan Memahami Diri Sendiri. Jakarta: Bina Rupa Aksara, 1997.

Macartney.C.E. Trial of Great Men of the Bible. New York: Abington, 1969.

Robert R. Boehlke. Sejarah Perkembangan dan Praktek PAK: dari Yohanes Amos Comenius hingga Perkembangan PAK di Indonesia. Jakarta: BPK-Gunung Mulia, 2011.

Robert Pazmino. Fondasi Pendidikan Kristen. Jakarta: BPK Gunung Mulia, 2012.

Stanley Heath (edisi Revisi). Psikologi yang Sebenarnya. Yogyakarta. Yayasan Andi, 1999.

Sugiyono. Memahami Penelitian Kualitatif. Bandung : Alfabeta, 2005

Suryabrata, Sumadi. Psikologi Kepribadian. Jakarta: Raja Grafindo Persada, 2015.

Swindoll, Charles. Moses: A Man of Selfness Dedication. Dallas, Texas: World Publishing, 1999.

Von Rad. Musa. Jakarta: BPK Gunung Mulia, 1973. 
W.J.S Poerwadarminta. Kamus Umum

Bahasa Indonesia. Balai Pustaka:

Jakarta, 2003.

https://www.dictio.id/t/apa-yang-

dimaksud-dengan-temperamen-

manusia/8861

http://www.sarapanpagi.org

http://c3i.sabda.org/temperamen_flegmatik 